\title{
COMPETITION AND PUBLIC SERVICE BROADCASTING: STIMULATING CREATIVITY OR SERVICING CAPITAL?
}

Centre for Business Research, University of Cambridge

Working paper No. 408

by

\author{
Simon Turner \\ Department of Health Services Research and Policy, \\ London School of Hygiene \& Tropical Medicine, \\ Keppel Street, London, \\ WC1E 7HT \\ Email: simon.turner@lshtm.ac.uk
}

\author{
Ana Lourenço \\ School of Economics and Management, \\ Catholic University of Portugal, \\ Rua Diogo Botelho, 1327, 4169-005, \\ Porto, Portugal. \\ Email: alourenco@porto.ucp.pt
}

June 2010

This working paper forms part of the CBR Research Programme on Corporate Governance 


\begin{abstract}
In UK public service broadcasting, recent regulatory change has increased the role of the private sector in television production, culminating in the BBC's recent introduction of 'creative competition' between in-house and independent television producers. Using the concept of 'cognitive distance', this paper focuses on the increasing role of the independent sector as a source of creativity and innovation in the delivery of programming for the BBC. The paper shows that the intended benefits of introducing new competencies into public service broadcasting have been thwarted by, on the one hand, a high level of cognitive proximity between in-house and external producers and, on the other, a conflict in values between the BBC and the independent sector, with the latter responding to a commercial imperative that encourages creativity in profitable genres, leaving gaps in other areas of provision. While recent regulatory reform appears to have had a limited impact on the diversity of programming, it does suggest a closer alignment of programme content with the imperatives of capital. Implications for the literature on communities of practice are noted.
\end{abstract}

\title{
Acknowledgements
}

An earlier version of this paper was presented at the Society for the Advancement of Socio-Economics conference, Sciences Po, Paris, 16-18 July 2009. We are grateful to participants in the session on regulating capitalism for their very useful comments, and to Sue Konzelmann in particular for proposing and moderating the session. We should also like to thank Simon Deakin and Stephen Pratten for their support with the empirical research and for their comments on previous drafts.

JEL Codes: L14, L22, L23, L24

Key words: cognitive distance, governance, public sector reforms, networks

\section{Funding}

This study was supported by the European Union's Sixth Research and Development Programme, Integrated Project CIT3-CT-2005-513420, Reflexive Governance in the Public Interest ('Refgov').

Further information about the Centre for Business Research can be found at www.cbr.cam.ac.uk 


\section{Introduction}

In UK public service broadcasting, recent regulatory change has increased the role of the private sector in television production, culminating in the BBC's introduction of 'creative competition' between in-house and independent television producers ('indies'). The Window of Creative Competition (WOCC), established under the BBC Charter and Agreement in April 2007, requires that $25 \%$ of programmes commissioned by the BBC are open to external competition, 'to maximise the quality of on-screen programming by creating a meritocracy for ideas' (BBC Trust, 2008, p. 31). This motivation is line with, but in addition to, the existing 25\% independent television production quota specified in the 1990 Broadcasting Act. Indies have been successful in the WOCC, winning three quarters of the commissions available through the competition (Ibid, p. 33). These regulatory and organisational changes can be understood as an attempt to promote creativity and diversity in programming by exploiting a domain of production competencies outside the BBC. This accords with the rise of market-oriented thinking in UK government policy in the organisation of the delivery of public services since the late 1970s. This paper argues that, while such changes appear to have had a limited impact on the diversity of programming, they do suggest a closer alignment of programme content with the imperatives of capital.

This argument is developed by viewing the reforms through two contrasting theoretical lenses, communities of practice (CoPs) theory and the analysis of institutional change. The first part of the paper traces the impact of reform on the television production communities serving the BBC. In the field of organisational learning, a body of literature has grown up which examines learning and innovation through interfirm relationships. In particular, the concept of 'cognitive distance' has been developed to predict the virtue of collaboration among different economic units according to their variation in knowledge and competencies (Nooteboom, 1999; 2000; 2008). Mutual understanding will be promoted among individuals who share similar mental schemas (cognitive proximity), but creativity is more likely to arise from the interaction of individuals with differing competencies (cognitive distance), as 'the friction of competing ideas can ignite innovation' (Nooteboom, 2008, p. 129). Although competencies may vary between organisations, such differences cannot be understood without referring to the more fundamental environment or social 'milieu' constitutive of cognition, as the mental schemas of individuals reflect the social and material environment in which their 'categories of thought' have developed. The locus of competencies can be situated within more pervasive organisational forms that span firms such as CoPs. These groupings 
consist of members that learn and develop knowledge through repeated interaction without necessarily belonging to the same formal organisation. The regulatory and organisational reforms affecting the BBC can be analysed by examining their impact on the sociology of learning within production CoPs, understood as a key source of creativity for the BBC and other television producers within the broadcasting industry.

While affording a fine-grained analysis of innovation practices, microperspectives on creativity such as CoPs theory have received criticism for neglecting the wider institutional and regulatory context of industries and its enduring influence on the prospects of firms (Roberts, 2006; Lave, 2008). The second part of this paper addresses this issue by deconstructing the reforms to the broadcasting industry as a socio-political process of institutional change. By creating new rules and practices of interaction, processes of institutional change impinge upon or afford new forms of behaviour among firms and communities. Attending to the agents of change, in this case the actions of government and industry stakeholders, is critical in order to account for the character of the production landscape that emerged through the reforms. Taking into account change in the dynamics of communities and institutions, this article addresses two questions: how does the variety of competencies available to the BBC through the WOCC arrangement contribute to the delivery of effective public service broadcasting; and what effect has institutional change had on the strategies of commissioned organisations and creativity and diversity in programming?

In the next section, the construct of cognitive distance among communities (2.1) and processes of institutional change are described (2.2). The methodology used to conduct the research on the UK broadcasting industry is then described in section 3, prior to the presentation and evaluation of the findings from the empirical work (sections 4 and 5).

\section{Innovation in communities and institutions}

\subsection{Cognitive variety}

The notion of cognitive distance represents the level of variation in the interpretive schemes of different individuals. Cognition is understood as the 'mental schemas' through which individuals perceive, interpret, and generally make sense of the environment. A schema is a meta-representation that subsists within the mind as 'an organized framework of objects and relations that has yet to be filled in with concrete detail' (D'Andrade, 1995, p. 122). Individuals develop schematic scenes or pictures through participation in activity and in response to socio-cultural experience. This idea meshes with a social 
constructivist theory of knowledge which situates practices of learning within specific social contexts and cultural communities. As Nooteboom (1999) notes, social embedding produces variation in practices of knowing: 'If knowledge is contingent upon categories of thought, and these develop in interaction with the physical and social environment, then cognition is path-dependent and idiosyncratic. People will be able to understand each other only to the extent that they have developed their categories in a shared environment and in mutual interaction' (p.140). Using the heuristic of cognitive distance, it is possible to imagine the collaborative relations between different agents according to a spectrum of interaction, defined at the one end by proximity and understanding and at the other by distance and novelty.

At the level of the firm, evolutionary approaches suggest that cognition is embedded in the firm's collective routines that allow organisations to perform a range of behaviour competently. As with the performance of individual skills, organisational routines are programmatic, tacit and, with frequent use, performed automatically (Nelson and Winter, 1982). The negative corollary to the 'automaticity' of routine behaviour is the loss of diversity and flexibility in performance. In a dynamic market environment, firms need to adapt their routines to innovate and sustain a competitive advantage. To overcome cognitive proximity, organisations seek access to external knowledge through a variety of interfirm relationships, from arm's length market-based contracts through to more collaborative hybrid or network forms (Powell, 1990; Deakin et al., 2009).

The effect of cognitive variety on organisational learning can be studied at an intermediate ontological level, the dynamics of communities situated within or beyond the hierarchy. Learning takes place through the everyday practices of social communities that do not necessarily coincide with the formal boundaries of the firm, such as CoPs (Wenger, 1998) and epistemic communities (Cowan et al., 2000). Although both groups learn through repeated interaction and developing a common purpose, the social dynamics of their knowledge practices vary. With regard to the public sector, Amin and Roberts (2008) suggest that professional CoPs learn through social interaction, apprenticeship, and mastery of professional knowledge; tend towards incremental innovation and the preservation of existing skills; and are subject to regulation that inhibits radical change (e.g. by professional associations). Conversely, epistemic communities associated with the creative industries (including scientists, researchers, and media workers) produce innovation through exploratory projects that bring together a variety of actors; depend on mobilising 'variety, ambiguity, and uncertainty' (p. 361); and are held together by peer recognition, project loyalty, organised slack and informality, and adherence to a common language and 
codes. Clearly, epistemic communities thrive on exploiting new connections and sustaining cognitive distance, while the durable ties characteristic of CoPs makes them more adept at developing a specific domain of knowledge achieved through cognitive and institutional proximity. However, the practices of both types of community are likely to spill over the boundaries of the firm, with epistemic groupings in particular likely to draw on interfirm practices of knowledge creation.

In television production, interpersonal and interfirm collaboration are frequently used to mobilise tacit knowledge that is crucial in commissioning content, due to the experiential nature of programming as a cultural good (Lampel et al., 2000). The last two decades of regulatory reform within the UK broadcasting industry represent a move away from vertical integration as a means to manage knowledge and creativity, which supposes the coordination and control of technical and creative employees within the firm, towards hybrid forms such as project networks and 'latent organisations' (Starkey et al., 2000) that are organised to exploit the cognitive variety of epistemic communities. In the latter forms of organisation, a network broker brings together temporary groups of individuals and independent firms that interact through time to deliver programme content. The repeated interaction between professionals, based on previous experiences of working together and expectations of future dealing, may favour the emergence of relational rules that underpin collaboration and sustain epistemic communities. However, collaboration across organisational boundaries also carries 'relational risk', due to an absence of social capital or trust among partners, which 'requires familiarity and mutual understanding and, hence, depends on time and context, on habit formation, and on the positive development of a relation' (Nooteboom et al., 1997, p. 314).

In the absence of vertical coordination, interfirm relations are governed by the institutional environment that characterises different spaces of economic activity. This includes the informal conventions of interaction associated with communities, but it also extends to more systematic arrangements for coordinating economic exchange including contracting regimes, legal rules, property rights, and regulation and industrial policy in general (North, 1990). The influence of institutional embedding on practices of creativity is now discussed.

\subsection{Institutional analysis}

New institutional economics draws attention to the institutional arrangements in which the activities of firms and communities are embedded. Institutions are read as 'the humanly devised constraints that structure human interaction' (North, 1993, p. 360). These include formal rules and laws as well as informal 
conventions and norms of behaviour. While the concept of CoPs emphasises the informal basis of learning through mutual interaction, less attention has been paid to the influence of formal institutional mechanisms on the sociology of their practices. Perhaps a feature of the ethnographic methods often used by researchers to provide fine-grained descriptions of the everyday practices of CoPs, there remains a tendency to view these groups 'from within' (e.g. Gherardi, 2009). By contrast, institutional analysis - in viewing social practices as shot through with institutional rules of varying origin and formality - creates a space for analysing the relationship between communities and the institutions that shape their practices.

The influence of formal institutions on organisations and communities can be observed in institutional change, as this has the capacity to alter the behaviour of these groups. The opportunities created by the dominant institutional framework will heavily influence the types of organisations that emerge within an industry and their evolution (North, 1990). However, there is no consensus in the literature about the relevant actors or processes by which institutional change is brought about. The varieties-of-capitalism approach argues that firms are key agents of change, 'constrained by the existing rules and institutions but also looking for ways to make institutions work for them' (Hall and Thelen, 2009, p. 10). This macro-level perspective has been criticised for its preoccupation with the style of national institutions as this hides the variety of institutional arrangements that exists within economies. For example, Crouch et al. (2009) show that local or regional institutional environments can often deviate from the national model, based on the development by companies of local governance structures that meet their own market needs. In accounting for local variation, one can point towards the action of 'institutional entrepreneurs' that participate in 'changing and creating the institutional contexts within which innovators in the normal sense operate' (Crouch, 2007, p. 3). This actor-centred perspective on innovation resonates with the theory of CoPs as both see creativity manifest in the building of collective relations among self-organising agents. However, both perspectives lend considerable weight to the informal organisation of innovation-seeking groups, but pay little regard to the structural constraints imposed by the broader institutional environment, including the competing interests of other social and political agents.

The equation of institutional change with the actions of self-interested firms has been met with resistance from other scholars for neglecting the interests of government and political conflict in processes of change (Howell, 2003). For varieties-of-capitalism analysts, even governmental reform is viewed 'as a process built on coalitional politics, in which segments of capital are usually pivotal' (Hall and Thelen, 2009, p. 20). As pointed out by Howell (2003), this 
implies a secondary role for states who 'act largely at the behest of employers' (p. 110). This creates a picture where 'capitalist political economies and the social relations that undergird them are fundamentally nonconflictual; the interests of different actors can be effectively coordinated for long periods by sets of institutions' (Ibid). This picture is deficient. Firstly, it assumes that firms are relatively homogenous entities and denies the varied interests, histories, market strategies, and governance arrangements that organisations possess. There are multiple interests at stake in institutional change and, based on their heterogeneity, new arrangements produce variegated outcomes for the actors involved. Secondly, it assumes that government policy is oriented towards the efficient functioning of market economies, with the consequent neglect of its broader regulatory role in governing relations between state, market and society (Wright, 2009). For example, despite undergoing two decades of market-based reform, the full marketization of UK broadcasting has been resisted due to concern about safeguarding the public service elements of broadcasting (Deakin et al., 2009). While aiming to meet the interests of firms, formal institutional arrangements are actually sanctioned by governments steering 'plural economies' composed of capitalist and non-capitalist interests (Amin, 2009).

These criticisms suggest that no straightforward relationship can be drawn between the firm and processes of institutional change. Institutions embody a diversity of interests and produce variegated effects, as they represent the outcome of imperfect relations among the state, heterogeneous firms, and communities. Institutional analysis not only implies studying how these actors are involved in the construction of institutions: it also means examining the effect that their formation has on the behaviour of firms and communities. Institutional analysis develops the theory of CoPs by situating the micropractices of innovation undertaken by firms and communities within a wider institutional framework that structures or orders those practices. Equally, employing a micro-theory of innovation such as CoPs develops institutional analysis by opening up a conceptual space in which the influence of regulatory and institutional change upon economic practice (i.e. innovation capacity) can be studied.

The empirical context for the analysis is the UK broadcasting industry, and specifically the deepening relationship between the BBC and the independent television production sector. Following a brief overview of the research methodology (section 3), the regulatory and institutional reforms affecting the UK broadcasting industry over the last two decades are reviewed. The empirical material is then presented. In section 4.1, the reforms are assessed against the aim of exploiting cognitive variety to bring new competencies to bear on programming commissioned by the BBC. In section 4.2, the implications of 
affording a greater role to indies in the delivery of BBC programming are evaluated from an institutional perspective. Concluding remarks on communities and institutions based on the case-study material are made in section 5 .

\section{Methodology}

There are four public service broadcasters operating within the UK: BBC, Welsh Authority (S4C), providers of the licensed public service channels (Channel 3, Channel 4 and Five), and the public teletext provider (Teletext). As defined by statute in the 2003 Communications Act (c.21, section 264), public service broadcasting should: deal with a wide range of subject matter; be shown at a time relevant to audiences; be balanced in coverage; and be produced with a high standard of content, quality, and professional skill and integrity. The television sector is regulated by OFCOM (Office of Communications), an independent authority created under the 2003 Communications Act to replace five separate regulators of the communications sector, including the Independent Television Commission (ITC). OFCOM aims to further the interests of 'citizens' and 'consumers' by maintaining plurality in broadcasting provision and by promoting competition, where appropriate. The trade association for the independent production sector is PACT (Producers Alliance for Cinema and Television). Formed in 1991, PACT represents the interests of its members (over 450 companies) to governmental bodies (including OFCOM) and negotiates production terms with major broadcasters and other purchasers of media content. With 26,500 members, BECTU (Broadcasting Entertainment Cinematograph and Theatre Union) is the independent trade union for employees and freelance workers within the broadcasting industry.

The research is based on 15 semi-structured interviews with key stakeholders from the UK television industry conducted in the spring of 2008 (see Table 1). A bespoke aide-memoire was prepared for each interview and this acted as a checklist for discussing a number of key issues: the current composition of the UK television industry; the impact of recent regulatory and organisational changes on broadcasters and indies, notably the change in the terms of trade and the introduction of the WOCC; the likely sources of creativity and quality in contemporary programming and the effect of institutional pressures; and the advantages and disadvantages of making programmes through in-house and independent television production teams. The interviews (which lasted for an hour on average) were tape-recorded and transcribed in full. The transcripts were reviewed by the project team and the evidence was categorised into different themes based on our reading of the interview data. It was at this stage that the concept of cognitive variety was recognised to be of value in interpreting the recent regulatory and organisational reforms within UK 
broadcasting. As such, the process of research adopted a 'grounded theory' approach (Glaser and Strauss, 1967) involving the generation of theory through the conduct of qualitative research, rather than collecting data that merely supports the tenets of extant theory.

\begin{tabular}{|l|l|}
\hline Organisation & Interviewees \\
\hline Ofcom & Policy director; Economic advisor \\
\hline BBC & $\begin{array}{l}\text { Programme commissioner; Channel controller; Senior producer; } \\
\text { R\&D manager }\end{array}$ \\
\hline BBC Trust & Trustee \\
\hline Channel 4 & Policy director \\
\hline PACT & Senior executive \\
\hline BECTU & Secretary \\
\hline Small indie & Proprietor \\
\hline Mid-size indie & Managing director; Finance director \\
\hline Large indie & Chairman \\
\hline Publicly quoted indie & Commercial director \\
\hline Table 1 Lit of invien
\end{tabular}

Table 1. List of interviewees

The strength of an interview-based approach is that, by affording the collection of in-depth, discursive material from a range of voices, it enables the complex effect of regulatory reform upon the organisational strategies of multiple actors to be described. A wider range of actors was approached for interview, including a further number of prominent indies and broadcasting professionals, but our requests were either declined or no response was received. The study is based on a limited volume of interview data but the perspectives of the main players within the industry (including a range of indie types) are represented. In order to triangulate the evidence generated through the interviews, other forms of data were collected: quantitative information on the evolving composition of the independent production sector; documents mapping the relationships between the $\mathrm{BBC}$ and the largest independent suppliers of programming; and information on innovation and diversity in the BBC's programming output over time.

\section{Regulatory change and UK public sector broadcasting}

The BBC was formed under General Manager John Reith in the 1920s with the purpose 'to inform, educate and entertain'. The BBC currently has an annual income of $£ 4.6$ billion (75\% comes from the licence fee) and employs 23,000 staff (BBC, 2009). In relation to public value, the BBC's stated mission outlined in the current Royal Charter and Agreement (2006) repeats Reith's mantra and sets out six public purposes including sustaining citizenship, promoting learning, stimulating creativity, and representing the nations, regions, and communities of the UK. According to Born (2004), these Reithian or public service values continued to motivate the television production departments within the BBC in 
the 1990s: 'A continually evolving Reithianism animated the BBC's production cultures, as for decades it had informed the shared craft of British broadcasting... it formed part of the collective expertise and implicit knowledge of programme-makers' (p. 84). In language reminiscent of the literature on CoPs, Born argues that BBC producers identified with a history of programmemaking inflected with Reithian ethics and crafted in particular aesthetic styles, such that 'their attempt to forge knowing links between generic pasts and imagined generic futures was their primary mode of professional engagement' (p. 84-5). The 'public service ideal' was present in the critical, self-reflexive stance of practitioners and debated in editorial and output review meetings, 'So [came about] the desire to innovate in the look or tone of a particular genre, or the inclination to tweak a rival's successful format, or criticism of others for failing to deliver on a necessary BBC commitment to popularity or distinctiveness' (p. 85).

Over the last two decades, regulatory and institutional change has altered the internal organisation of production within the $\mathrm{BBC}$ and changed the relationship with the external television production sector. Following the publication of the Peacock Report in 1986, the BBC was reorganised in accordance with the principles of 'quasi-markets' (Le Grand and Bartlett, 1993) as programmemakers were separated from programme commissioners, the suppliers of production resources, to facilitate the benchmarking of costs. The 1990 Broadcasting Act introduced a production quota for the BBC and ITV which meant that $25 \%$ of programming by volume had to be contracted out to indies. Following a review of the programme supply market by the Independent Television Commission (ITC, 2002), a new wave of reforms addressed the perceived bias towards incumbent perspectives in the relationship between terrestrial broadcasters and the independent production sector. The 2003 Communications Act realigned the contractual 'terms of trade' between broadcasters and indies signalling a move away from 'full funding' contracts to a 'licensing' model whereby producers would meet the costs of production but retain ancillary rights to the future exploitation of licensed programmes in the UK and internationally. This represented the adoption of the ITV terms of trade, and the decline of the BBC convention of awarding fully-funded contracts with the transfer of rights. This regulatory change helped facilitate the transformation of the sector from 'a pure "cottage" industry of talented creatives, beholden to the main broadcasters, to one in which several leading companies now generate significant revenues and profits and have attracted the renewed interest of the City' (Mediatique, 2005, p. 3). In April 2007, the BBC's introduction of the WOCC extended the involvement of the independent sector by opening up a further $25 \%$ window of programming to competition from in-house and external production teams. 
The UK government gives three reasons for supporting a greater role for the independent production sector in the delivery of public service broadcasting. Firstly, introducing competition among a range of producers will ensure the 'best' possible programmes are broadcast (the term 'efficiency' is also used in this context). The value of competition is largely treated as self-evident, 'Competition in the supply of programmes will tend to provide a better product for audiences' (DCMS, 2005a, p. 86). Secondly, the use of independent providers promotes plurality in programme content. The WOCC promises to 'deliver range and diversity, providing genuine opportunity for all types of independent producer (as well as the BBC itself) from all parts of the UK and across a wide range of output' (DCMS, 2006, p. 41). Thirdly, the independent sector is seen as a locus of 'creativity and innovation' in its own right that can deliver 'additional value' to the viewer (DCMS, 2005b, p. 9).

Since the late 1990s, a decline in the diversity of programming offered by the UK's public service broadcasters has been detected (Ofcom, 2004). In the five years prior to 2003, the volume of new UK-made programmes shown on terrestrial television fell dramatically in the genre of education (down 53\%), and at peak-time in current affairs (down 22\%), arts (down 23\%), and religion (down $12 \%)$. Over the same period, Ofcom's review suggested that BBC 1 was adopting an increasingly 'ratings-driven approach' showing a high proportion of drama programmes at peak-time, notably soap operas and long-running series, whilst BBC 2's peak-time volume of light entertainment and factual programmes (especially 'leisure' shows) grew at the expense of arts and drama programming. The review also gathered the views of broadcasting professionals on innovation and quality, with many feeling that 'they are having to adopt an increasingly copycat approach in search of ratings' (p.32) whilst viewers were found to 'resent being repeatedly presented with similar versions of the same format' (p.59). From 2004 to 2008, there has been a further decline in spending on programming by the BBC, with programme investment on BBC1 and BBC2 decreasing by $13 \%$ (Ofcom, 2009). The BBC's budget for investing in new content has also come under particular pressure from the need to invest in the development of new delivery mechanisms, including i-Player, HDTV, Freesat, and digital switchover support (Oliver and Ohlbaum, 2009). Despite these trends, the BBC is still rated highly by audiences compared with other public service broadcasters in the UK, with a recent Ofcom survey finding that the $\mathrm{BBC}$ channels scored highest on quality, originality, and being engaging, with only C4 rated better on innovation (Ofcom, 2009, p.64-65).

The growing influence of the independent sector in the provision of BBC programming also creates new uncertainties regarding the corporation's ability 
to deliver creativity and diversity in its output. In particular, concerns have been raised that extending the role of the independent production sector beyond the $25 \%$ quota may threaten the sustainability of the BBC's own production capability. The Work Foundation (2005) claims that, once the independent sector becomes larger than in-house production at the BBC, a 'tipping point' will be reached whereby 'independents will increasingly dictate the terms over what kind of programmes they want to make' while the BBC 'risks a serious hollowing-out as a creative organisation by a rapidly growing and newly empowered independent sector' (p.7). From the perspective of the television production communities identified by Born (2004), the institutional changes may also threaten the reproduction of these groups and the sociology of innovation of the broader media community in which they are situated. The consequences of this trajectory of change in the BBC's production strategy are now assessed from CoPs and institutional perspectives.

\subsection{Cognitive variety}

Following the 1990 Broadcasting Act, the attempt to create an external market for programme supply encountered a number of social and institutional effects that promoted a tendency towards cognitive proximity, marked by the reproduction of an inter-organizational community of television broadcasters and producers. Firstly, there was an outflow of 'indie trailblazers' from the BBC into the independent sector during the 1990s as 'Ex-BBC producers now operating as independents were offered more generous returns than had they remained in-house, raising program costs' (Born, 2002, p. 72). As Bryson et al. (1997) note, spin-offs carry the competitive advantage of accumulated expertise and industry contacts derived from working with the parent company. For example, of the top ten indies used by the BBC in 2007, only Tiger Aspect Productions and Wall to Wall Television were not founded or are headed up by staff formerly working within the BBC or other UK broadcasters (see Table 2). 


\begin{tabular}{|c|c|c|c|c|}
\hline $\begin{array}{l}\text { Production } \\
\text { Company }\end{array}$ & Founded & $\begin{array}{l}\text { Programme } \\
\text { Genre(s) }\end{array}$ & Key staff & Biography \\
\hline Kudos & 1992 & $\begin{array}{l}\text { Drama, } \\
\text { Comedy, } \\
\text { Factual }\end{array}$ & $\begin{array}{l}\text { Stephen Garrett } \\
\text { (Executive } \\
\text { Chairman) and } \\
\text { Jane Featherstone } \\
\text { (Creative Director) }\end{array}$ & $\begin{array}{l}\text { Garrett and } \\
\text { Featherstone left } \\
\text { Channel } 4 \text { to co-found } \\
\text { Kudos in } 1992\end{array}$ \\
\hline $\begin{array}{l}\text { Tiger Aspect } \\
\text { Productions }\end{array}$ & 1988 & $\begin{array}{l}\text { Children, } \\
\text { Comedy, } \\
\text { Drama, } \\
\text { Entertainment, } \\
\text { Factual }\end{array}$ & $\begin{array}{l}\text { Peter Bennett-Jones } \\
\text { (Chairman) }\end{array}$ & $\begin{array}{l}\text { Bennett-Jones was } \\
\text { Managing Director of } \\
\text { Talkback Productions } \\
\text { prior to founding Tiger } \\
\text { Aspect }\end{array}$ \\
\hline Endemol & 1994 & $\begin{array}{l}\text { Entertainment, } \\
\text { Factual, } \\
\text { Comedy }\end{array}$ & $\begin{array}{l}\text { Tim Hincks (CEO, } \\
\text { Endemol UK) }\end{array}$ & $\begin{array}{l}\text { Former producer of } \\
\text { BBC programmes }\end{array}$ \\
\hline $\begin{array}{l}\text { Hat Trick } \\
\text { Productions }\end{array}$ & 1986 & $\begin{array}{l}\text { Comedy, } \\
\text { Drama, } \\
\text { Entertainment }\end{array}$ & $\begin{array}{l}\text { Jimmy Mulville } \\
\text { (Managing } \\
\text { Director) }\end{array}$ & $\begin{array}{l}\text { Mulville worked in } \\
\text { BBC radio and } \\
\text { television before co- } \\
\text { founding Hat Trick } \\
\text { with Denise } \\
\text { O’Donoghue and Rory } \\
\text { McGrath in } 1986\end{array}$ \\
\hline $\begin{array}{l}\text { Talkback } \\
\text { Thames }\end{array}$ & 2003 & $\begin{array}{l}\text { Drama, } \\
\text { Comedy, } \\
\text { Entertainment, } \\
\text { Factual }\end{array}$ & $\begin{array}{l}\text { Lorraine } \\
\text { Heggessey (CEO) }\end{array}$ & $\begin{array}{l}\text { Heggessey left position } \\
\text { as controller of BBC1 } \\
\text { to become CEO of } \\
\text { Talkback Thames in } \\
2005\end{array}$ \\
\hline Lion Television & 1997 & History & $\begin{array}{l}\text { Richard Bradley, } \\
\text { Nick Catliff and } \\
\text { Jeremy Mills } \\
\text { (Managing } \\
\text { Directors) }\end{array}$ & $\begin{array}{l}\text { Bradley, Catliff and } \\
\text { Mills left the BBC to } \\
\text { co-found Lion in } 1997\end{array}$ \\
\hline $\begin{array}{l}\text { Shed } \\
\text { Productions }\end{array}$ & 1998 & Drama & $\begin{array}{l}\text { Eileen Gallagher, } \\
\text { Brian Park, Ann } \\
\text { McManus, } \\
\text { Maureen Chadwick } \\
\text { (founders) }\end{array}$ & $\begin{array}{l}\text { Gallagher, Park, } \\
\text { McManus and } \\
\text { Chadwick left Granada } \\
\text { Television (part of ITV } \\
\text { productions) to co- } \\
\text { found Shed in } 1998\end{array}$ \\
\hline $\begin{array}{l}\text { Wall to Wall } \\
\text { Television }\end{array}$ & 1987 & $\begin{array}{l}\text { Factual, } \\
\text { Drama }\end{array}$ & $\begin{array}{l}\text { Alex Graham } \\
\text { (CEO) }\end{array}$ & $\begin{array}{l}\text { Graham worked as a } \\
\text { reporter and editor in } \\
\text { the press before } \\
\text { founding Wall to Wall } \\
\text { with Jane Root. In } 1997 \\
\text { he acquired her shares } \\
\text { as she left to run BBC2. }\end{array}$ \\
\hline 12 Yard & 2001 & Game shows & David Young & Young left position as \\
\hline
\end{tabular}




\begin{tabular}{|l|l|l|l|l|}
\hline Productions & & & (founder) & $\begin{array}{l}\text { BBC's Head of Light } \\
\text { Entertainment to } \\
\text { establish 12 Yard in } \\
2001\end{array}$ \\
\hline Carnival Films & 1978 & $\begin{array}{l}\text { Drama, } \\
\text { Comedy }\end{array}$ & $\begin{array}{l}\text { Gareth Neame } \\
\text { (Managing } \\
\text { Director) }\end{array}$ & $\begin{array}{l}\text { Neame left position as } \\
\text { BBC's Head of Drama } \\
\text { Commissioning to join } \\
\text { Carnival in 2005 }\end{array}$ \\
\hline
\end{tabular}

Table 2. Top ten independent suppliers to BBC Vision by spend in 2007.

Secondly, the high concentration of media companies in London ${ }^{1}$, the majority of which are located in the district of Soho, affords informal interaction outside work in the city's pubs and cocktail bars that engenders common 'norms of thinking and ways of doing which transcend individual firms and industry boundaries but characterise the cluster as a whole' (Nachum and Keeble, 1999, p. 30-31). Thirdly, the mobility of freelance workers, who represent the majority of employees in the independent sector and over a quarter of workers within UK broadcasting organisations, generates knowledge spillover effects as workers carry new ideas and tacit knowledge between firms. Finally, the BBC has shown a preference for developing long-term relationships with a limited range of producers, citing the benefits of secure relationships for stimulating creativity and risk taking among programme makers, while causing 'considerable disquiet among those independents who perceived that they were unfairly penalized by such a system' (Deakin and Pratten, 2000, p. 343). The commissioning system remained embedded in a set of social conventions familiar to broadcasting professionals, favouring production companies set up by former employees with experience of those practices and an established reputation. These processes supported the reproduction of 'communities of ideas' united by a commitment to an imagined set of Reithian values that regulated the trajectory of programme making across different genres by encouraging producers to steer away from as much invention as that which they engendered. Television producers shared a mutual understanding of aesthetic styles and ethics, cognitive proximity in other words, which was not confined to producers within the BBC, as 'their output formed part of these histories, connecting them to a wider professional world beyond the BBC and to common, genre-specific concerns' (Born, 2004, p. 84).

This outcome could be read as an attempt by commissioners to maintain the CoPs composed of broadcasters and commissioners situated within the formerly vertically-integrated structure of the BBC. While such systems of learning have been recognised in the literature as significant sources of apprenticeship learning and everyday socialisation (Lave and Wenger, 1991), there is greater doubt about the ability of CoPs to engender a diversity of perspectives and thereby 
produce radical learning or innovation. How have the more recent reforms since 2003 affected the reproduction of the competencies associated with these production communities? In response to the WOCC, the BBC Trust (2008) states that the BBC aimed to reduce the capacity of in-house production teams by 15\%, with almost 600 redundancies made between 2005 and 2008 . Mediatique (2005) notes that further downsizing of the BBC caused by the WOCC 'is likely to create a renewed flow of talent to the independent sector' (p.8). In 2007, the BBC commissioned programmes from 211 different indies, including 59 newly commissioned, a moderately higher number than in the two preceding years. However, the figures relating to new production relationships are being treated with caution by the BBC Trust (2008), having been informed that 'independent production companies were often set up by key figures from other companies, or by people who have recently left the BBC. As such, these production companies might already have established personal relationships with commissioners' (p.65). Television producers working within both the BBC and independent production companies were still perceived to share similar characteristics, as a BBC programme commissioner told us in interview:

now we just regularly get them all together and actually the in-house discovers that actually they are just like them. They are all about the same age, they generally come from the same social background, and actually the only difference is one is outside the BBC and one is inside.

In addition to possessing some similar cognitive characteristics to incumbent producers, it is not clear whether the range of indies commissioned by the BBC accords with the principle of variety. The BBC's preference for maintaining relationships with familiar contacts has continued since the introduction of the WOCC, as the commercial director of a 'super-indie' informed us in interview,

the other key ingredient that I think all of us indies have is that we're looking for people out there who have got good relationships with the right people at Channel 4, Channel 5, BBC, and can therefore pick up the phone, walk in the door, even mention over lunch we've got a great idea. It also means that the broadcasters come to you first or come to these people first for things and that makes a huge difference.

The use of a narrow range of indies may allow the BBC to reduce relational risk by developing durable relationships that seed mutual understanding and trust but, at the same time, the tendency to recommission existing producers may reproduce the same routines, to the detriment of exploration or novelty-seeking behaviour that would encourage the breakthrough of new companies. In a survey 
conducted in 2005, Ofcom estimated that $70 \%$ of the externally commissioned programmes made for the BBC were produced by companies with a turnover of over $£ 12$ million (Ofcom, 2005). Of the indies commissioned in the year after the WOCC was introduced, the BBC Trust (2008) reports that 240 had an annual turnover of less than $£ 12$ million and 19 had annual revenues in excess of $£ 50$ million $^{2}$. This suggests that the majority of smaller indies commissioned by the $\mathrm{BBC}$ are each producing a limited volume of programming.

In addition to commissioning indies, another source of variety for the BBC is their use of freelance workers: 'They bring enormous talent, often with more than a dash of genius, to British programme-making, and it is the BBC's job to support them in creating great original work' (BBC, 2004, p. 101). Under the WOCC regime, there is greater pressure on the BBC to mimic the independent sector's flexible use of labour as the volume of programming commissioned from in-house production teams should vary from year to year, as the chairman of a large indie told us in interview:

there's some wastage of staff [at the BBC] because you've got some staff who are sitting around developing things hoping they're going to get a WOCC commission and that's not a very clever use of resources. We are much leaner and meaner because we only staff up when we get production, you know, where we have as many people as we need to service what we make.

The BBC's projected turn towards a regime of flexible production can be subjected to different interpretations. In private sector business networks, creativity is theorised to result from the interaction of a distributed community of actors that extends beyond the boundaries of the firm. Novelty or innovation is, or so corporate executives argue, the product of 'learning by switching ties' (Grabher, 2004). This intentionally 'disruptive' approach to project work is designed to exploit cognitive distance, as described by an art director based in London, 'You work with your favourites... but you also try new people, because of new ideas, new approaches... you look for freshness' (quoted in Grabher, 2004, p. 1501). In this view, a flexible labour market is a critical component of an epistemic community of workers that affords the continual reconfiguration of relationships in the pursuit of innovation. What this account of creativity omits though is that the use of flexible teams is made possible by a cognitive division of labour within these firms, as the pursuit of efficiency strips the epistemic content away from many roles beyond the 'core team'. In television production, the development of routinized formats allows programmes to be made using temporary staff assigned to roles within a Tayloristic production system, as described to us by a senior BBC producer: 
very frequently in an indie now the director is brought on after the pre-production work has been largely done, they're brought on just before the shoot. They do the shoot, they take the material into the edit where, because it's a highly formatted piece, they stay for the first two thirds of the edit and then leave for it to be completed by the series producer and editor. You may only be on contract to that production for eight, ten weeks; you will never see your programme completed. You are absolutely a gun for hire to do a job and the job's not a very creative one.

The BBC's own experience of using freelance production staff to reduce costs in the 1990s also indicates that employment on short-term contracts can inhibit learning and innovation, as Born's (2004) ethnography of the corporation highlighted: short working relationships undermined participation in 'creative dialogue'; opportunities for apprenticeship learning were stifled as junior staff were enrolled in distinct phases of production but unable to see whole projects through; commitment to training and providing professional development opportunities to casual employees declined; and production staff became weary of sharing new ideas as these were the currency by which new commissions or future employment could be secured ${ }^{3}$. The casualisation of employment also undermined commitment or loyalty to the BBC, as 'the public service ethos at its core was attenuated by the new contractualism' (Born, 2004, p. 191).

Although the BBC Trust's (2008) first biennial review of the WOCC reports inhouse production teams 'raising their game' and 'rising to the challenge of increased competition' (p.11), evidence was also found that the redundancies caused by the restructuring had affected morale and increased anxiety among producers. As a policy director from C4 told us in interview, the organisational changes at the BBC highlight the balance that needs to be struck between fostering a secure institutional environment designed for experimentation that 'allows for making mistakes and getting it wrong and learning from the mistakes and moving on', and maintaining a competitive tension which ensures that production teams do not 'settle down into comfort zones just repeating what you have been doing for years'. As we noted above, the BBC claims to respond to this tension by using freelance producers to bring new competencies to bear on in-house programming and thereby increase the level of cognitive distance or variety available during the production process. If, however, the pursuit of flexibility comes at the cost of the reproduction of 'public service values', then the injection of variety into the corporation may tip over optimal cognitive distance, undermining in-house collaboration and the personal commitment of staff to the BBC. This risk is also identified by the Work Foundation (2005) who claim, in keeping with CoPs theorists, that creativity stems from 'freedom, 
autonomy, good role models, resources (including time), encouragement, freedom from criticism, and norms in which innovation is prized and failure is not regarded as fatal' (p. 17).

In summary, opening a new window for the independent sector to compete for the provision of $\mathrm{BBC}$ programming has not led to the acquisition of the variety of new competencies as perhaps intended. In part, this is due to the continued displacement of BBC producers into the independent sector caused by the organisational reforms, a swathe of whom now have supplier relationships through spin-off companies. If many of the independent production companies used by the BBC are headed up by former staff this raises doubts about whether increasing the potential window for the commissioning of external organisations will introduce additional competencies, as the new programme makers may well have developed their own knowledge inside the same institution, only now supplying the BBC as newly-formed spin-offs. More importantly, the BBC's apparent reliance on a limited range of suppliers to deliver the majority of independent programming does not necessarily accord with the plurality of provision desired when the WOCC was introduced.

Notwithstanding this cognitive proximity, the private equity funding of these spin-offs may also add an element of profit orientation that works as a disruptive element of existing common practices, as cases like "Crowngate" seem to show ${ }^{4}$. The recent changes in the relationship between the BBC and the independent production sector appear to signal a shift away from what Amin and Roberts (2008) term 'professional CoPs' to the use of epistemic communities in television production. With regulatory and managerial sponsorship, the BBC is turning towards a 'mixed ecology' of production based on strengthening the linkages with external sources of knowledge, embodied within freelance producers and independent production companies, to generate innovation through the interaction of a variety of actors that extends beyond the formal boundaries of the corporation. As the BBC's own production capacity is eroded, the self-policing of norms and quality conventions attributed to professional CoPs is threatened by a new organisational logic that thrives, not on the stewardship of well-established routines and reproduction of existing competencies, but on the management of a distributed network of relationships to produce dynamic or innovative capabilities (Teece et al., 1997). This change also exposes the BBC to greater 'relational risk' stemming from setting up commissioning relationships with a higher proportion of independent organisations. This article now examines the effect of institutional change upon relations between the BBC and the independent television production sector. 


\subsection{Institutional change}

Following the 1990 Broadcasting Act, the BBC was able to propagate its own culture of production (loosely based on imagined Reithian values) when engaging with the independent sector. The 2003 reform in the terms of trade created a more profitable but concentrated independent television production sector. Mediatique (2008) estimates that the independent production sector generated revenues in excess of $£ 2$ billion in 2007, having more than doubled in size since 2000 when annual income stood at $£ 960$ million. This has been accompanied by a halving in the number of indies from 800 in the mid-1990s to around 400 at the present time (Doyle and Paterson, 2008). Due to a flurry of acquisitions over the last decade (see Table 3), the sector is becoming increasingly concentrated with the top 10 independent companies accounting for $65 \%$ of the market in 2007 (Mediatique, 2008). The 'tail' of small independents with annual turnovers of less than $£ 2$ million have seen their market share decline from 61\% in 1993 to just 2\% in 2007 (Ibid).

These changes in the composition of the industry can be related to regulatory and institutional change, as this afforded the growth of large production companies able to attract capital investment through stock market floatation or private equity finance. The improved terms of trade for indies when supplying broadcasters were the product of the government's desire to reduce the Public Service Broadcasters' market power identified in the ITC's review as well as political lobbying from PACT, the producer's association. To understand the emergence of this institutional change it is critical to review the steps that led to the publication of the 2003 Communications Act. A draft Bill was published by the government in May 2002. This proposed simplifying the regulation of the media, through the creation of a single regulator (Ofcom), and by relaxing the rules on media ownership. A joint parliamentary committee, chaired by Lord Puttnam, conducted a pre-legislative review of the draft Bill that summer. The inquiry heard evidence on the proposed reforms from a series of stakeholders, including PACT, the BBC, and the government. The committee agreed with PACT that the draft Bill neglected the needs of indies:

The draft Bill is almost wholly concerned with the interests of broadcasters, channels and platform owners and has little to say about the need to create a competitive market producing high quality content which can appeal domestically and internationally. ${ }^{5}$

Evidence was also taken from Greg Dyke, then Director-General of the BBC, who questioned PACT's motive for seeking a code of practice that would formalise relations between broadcasters and independent suppliers:

Remember the Independent Producers' Organisation is only a trade organisation of people trying to make money and, therefore, you 
should not believe all people say as Gospel. These are people looking for the best interests of their businesses which is perfectly valid, but you have to set it in that perspective and, therefore, their aim is to maximise both the income and the rights ownership they can get, and the House's is to look after the public interest, so is it really our job to make large numbers of indies extremely rich? ${ }^{6}$

\begin{tabular}{|c|c|}
\hline Holding Company & Production Companies \\
\hline All3Media & $\begin{array}{l}\text { South Pacific Pictures, North One TV, Lion TV, Lime Pictures, } \\
\text { IDTV, Company Pictures, ARG TV, Cactus Films, All3Media } \\
\text { International, Bentley Productions, Maverick Media, MME } \\
\text { Movement }\end{array}$ \\
\hline IMG & $\begin{array}{l}\text { TWI, Tigress Productions, Tiger Aspect, Darlow Smithson } \\
\text { Productions }\end{array}$ \\
\hline RDF Media Group & $\begin{array}{l}\text { Touchpaper Television, RDF Media, RDF International, Radar TV, } \\
\text { IWC Media, The Comedy Unit, Presentable, Foundation TV } \\
\text { Productions }\end{array}$ \\
\hline Southern Star Group & $\begin{array}{l}\text { Oxford Scientific Films, Darrall Macqueen, Carnival Films and } \\
\text { Television }\end{array}$ \\
\hline Tinop & $\begin{array}{l}\text { Venner TV, Mentorn, Folio, Sunset \& Vine Productions, Music } \\
\text { Box, Tinopolis, Video Arts Group, APP Broadcast }\end{array}$ \\
\hline Shed Productions Plc & $\begin{array}{l}\text { Shed Productions, Ricochet, Outright Distribution, Twenty Twenty } \\
\text { Vision, Wall to Wall }\end{array}$ \\
\hline ITV Productions & 12 Yard Productions \\
\hline Endemol UK & $\begin{array}{l}\text { Endemol, Cheetah, Initial, Zeppotron, Brighter Pictures, } \\
\text { Showrunner, Hawkshead, Victoria Real }\end{array}$ \\
\hline $\begin{array}{l}\text { Fremantle Media (RTL } \\
\text { Group) }\end{array}$ & $\begin{array}{l}\text { Fremantle Media, Talkback Thames, Grundy Productions, Regent } \\
\text { Productions }\end{array}$ \\
\hline DCD Media & $\begin{array}{l}\text { Box TV, Done and Dusted, Iambic Productions, Prospect Pictures, } \\
\text { September Films, West Park Pictures }\end{array}$ \\
\hline Hit Entertainment & $\begin{array}{l}\text { Hit Entertainment, Gullane Entertainment, Hit USA Production, } \\
\text { Guiness World Records }\end{array}$ \\
\hline Medi & lemol \\
\hline Ten Alps Plc & Blakeway/3BM, Brook Lapping, Ten Alps TV, Production Co \\
\hline The Zodiak G & e TV, Diverse Productions UK and US \\
\hline & \\
\hline Shine & Shine, Firefly, Kudos, Princess \\
\hline
\end{tabular}

Table 3. Merger activity since 2006 (PACT in Perspective, 2009)

Note: Since its publication there have been changes to the data displayed: for instance, IMG sold its companies Tigress Productions, Tiger Aspect and Darlow Smithson Productions to Endemol UK, and Southern Star Group sold Carnival to NBC Universal. 
Tessa Jowell, then culture secretary of the government stated, in turn, that the public money allocated to the BBC should also fulfil a wider role in supporting the creative economy, opening up new regulatory terrain at the interface between the BBC and the independent sector:

In relation to the broader position of the independent producers, we would look very closely at ways in which independent producers would be disadvantaged or discriminated against. I have said on many occasions that I see, for instance, one of the functions of the licence fee, the $£ 2.5$ billion which is available to the BBC, as being in a sense venture capital for the nation's creativity, and the use of certainly part of that resource to drive a healthy independent sector is very important indeed. $^{7}$

At the government's request, the publication of the Puttnam report led to a review of the relations between television broadcasters and producers by the incumbent regulator (ITC, 2002). The government accepted the majority of the findings of this review, including the need for 'terms of trade between broadcasters and independent producers [that] are fair and foster an economically sound independent production industry' (DCMS, 2003). The institutional 'rules of the game' (North, 1990, p. 3) governing the commissioning of programming had changed. By allowing indies to retain the intellectual property rights to programmes, the new terms fuelled the dramatic growth in revenue of the independent sector during the 2000s: the independent production sector registered annual growth of $15 \%$ since 2005, with the top 15 indies seeing their revenue grow from $£ 1.1$ billion in 2005 to $£ 1.6$ billion in 2007 (Perspective, 2009). This was accompanied by a process of consolidation as many small to medium indies were sold to larger companies, leading to the emergence of heavily capitalized 'super-indies' propelled by external investment including opportunities for public floatation. For instance, the chair of PACT during the negotiations over the terms of trade, Eileen Gallagher, successfully floated her production company, Shed Media, on the AIM stock exchange in March 2005.

The BBC's roster of indies is currently dominated by these so-called 'superindies'. Of the top ten indies used by the corporation in 2007, seven are now owned or controlled by parent companies with annual revenues in excess of $£ 100$ million $^{8}$. As well as helping to fuel the growth of these companies, it is right to ask whether the change in the regulatory environment has altered the production strategies of indies. Faulkner et al. (2008) argue that, on the basis of having profit-oriented shareholders, larger production companies 'experience pressure to create programming that delivers a return' (p. 306). They provide the 
example of children's television producer HIT Entertainment (whose portfolio of programmes includes Bob the Builder as shown on BBC CBeebies) which generates half of its income through television revenue while 'the other half comes from consumer product licensing of dolls, models and other products that feature the character' (Faulkner et al., 2008, p. 307). For these authors, the representation of the independent sector by key stakeholders (producers, policy makers, and academics) as 'creative spaces that liberate the producer from the administrative and financial responsibilities found in large bureaucratic organizations like the BBC' (p. 297) is based on a Romantic dualism in which artistic values are separated from commercial imperatives, and claim instead that 'The artistic and the commercial exist in the same world, but the latter is hidden to keep the former sacrosanct' (p. 300). Preoccupied with the exploitation of secondary and tertiary rights, the independent production company, Faulkner et al. (2008) claim, 'does not so much liberate the creative producer as enmesh the producer-owner in new financial instrumentalities, which, on current programming evidence, generates as much chintz as it does art' (p. 314).

Our recent round of interviews shed some light on the conflicting imperatives facing larger indies. For example, the commercial director of a publicly quoted independent indicated that the likely response of the stock market was taken into account in programme decision-making:

you've got to satisfy the shareholders and promise things to the City and then deliver them. So, yes, of course it affects a lot of things in terms of driving the figures... it's probably one of the things that informs the policy: that we should have more returning series and formatted shows because they have more commercial value longer term. There are probably people here who would love to make more beautifully crafted documentaries on very interesting subjects but there's just not the money in it.

The ability to retain ancillary rights appears to encourage the production of programmes within genres likely to generate further returns, favouring, for instance, the making of entertainment formats rather than current affairs programmes or documentaries (as the latter tend to have little or no ancillary value). This interest in returnable genres does seem to reflect a profit motive, as indies 'with external shareholders, required to deliver profit growth year on year, and/or dependent on the vicissitudes of the stock market, are more likely to seek recurring income, re-commissions and long programme runs than to place greater emphasis on innovation and the approval of peers' (Mediatique, 2008, p. 15). Furthermore, the Work Foundation (2005) suggests that to maintain a low cost base independent companies are less likely to carry specialist departments (which they suggest act as a creative spur through inter-departmental 
interaction), and they provide anecdotal evidence that a concern with producing returnable formats among larger independents has reduced their interest in making one-off films for C4.

At the same time, the rise of the 'super-indies' has been associated with growing success in generating export revenue, especially through the supply of programmes to the US market. The UK independent production sector generated a record income of $£ 391$ million from overseas television sales in 2008 (The Guardian, 2009). Shed Media plc (2008) reports that $30 \%$ of its gross profit now comes from the US market, the penetration of which has been led by the commissioning of formats that have already been successfully broadcast in the UK, including BBC programmes World's Strictest Parents and Who Do You Think You Are?. In our recent round of research, we learned of the growing importance of international distribution to indies. Using development capital from stock market floatation or private equity sources, the larger indies are perhaps better positioned than in-house production teams to invest in new content. In particular, they have been able to construct transatlantic networks aligned to exploiting the multiple revenue opportunities available in both television markets, as it was put to us by the commercial director of a 'superindie',

we have people here who are creating ideas for new shows, new formats; if we can get those commissioned, particularly in the UK, (a) it drives production business in the UK, (b) it then delivers programmes and formats that we can sell internationally and market through the international division and (c) we can then take them to the US where we've got a very good chance of selling them into the US networks and then producing again through [the US subsidiary].

This 'super-indie', that possessed two international divisions (including one dedicated to distribution to the US market), informed us that most new formats produced for the UK market would also be marketed and sold internationally, and pitched to the US networks for production by the division for that region. In the fortnightly meetings between the executive producers and commercial directors of the company, intelligence regarding commissioning opportunities for broadcasters in both the UK and the US would be shared, and ideas for formats with potential in both markets would be encouraged by the commercial actors present.

These developments lend some support to critics of market-based reform, such as Georgina Born, who argue the government's assumption that the independent sector is a source of diversity and innovation is problematic. In a memorandum 
to the House of Lords Select Committee on the BBC's Charter Review, Born highlights the domination of the independent production sector by a handful of large companies, increasingly international in focus, that privilege 'the drive to increase profitability over the other social and cultural purposes befitting Britain's PSB system' (Born, 2005, p. 279). In her view, this results in the production of risk-averse, 'populist programming' that can secure 'safe commissions' with the major UK broadcasters and be reformatted for sale in other countries. At the same time, the increasing revenue stream of floated indies does allow them the financial slack to risk new ideas and new forms of content delivery, a strategy that has allowed them to acquire successfully export revenue by producing formats able to straddle the UK and US markets. However, such progress may hide a lack of appetite to compete for the commissioning of 'thoughtful' programming in less profitable areas of public service broadcasting, as it was put to us by a BBC Trust member.

This perspective, though, does not take account of the role of broadcasting organisations in determining the content and style of programmes commissioned. According to indies, their turn towards the US market was not only about pursuing additional sources of revenue, but was also the product of a decline in television revenue available in the UK. In particular, the transfer of ancillary rights from broadcasters to producers was perceived to be placing downward pressure on the tariff paid by broadcasters for primary licensing rights. The chairman of a large indie told us that establishing partnerships with production companies competing in other television markets may be necessary to cover the perceived shortfall in revenue:

we're having to invest upfront more of our ancillary revenue to cover the cost of production which means the shows become less profitable, are harder to make, harder to finance, and that's going to impact on things because it'll be harder to take the risks we've taken in the past because actually, if you like, our margin is going to thin. I think what you might start seeing, certainly in our area drama, and I imagine in reality as well, are shows that are structured with an eye on both sides of the Atlantic. In other words, that will only be possible to be made if you have an American partner, which we've never done before but may have to do in the future.

The BBC's predominant source of income remains the annual licence fee, a levy on all households that use a television. In 2007, the announcement of a diminished licence fee settlement triggered a six-year restructuring plan dubbed 'Delivering Creative Future' by the BBC's current Director-General, Mark Thompson. Coupled with the need to finance the development of new digital 
channels and a multimedia platform (including the BBC's iPlayer service), the settlement represented a move towards a more efficiency conscious corporation that would produce 'fewer, higher quality, programmes'. A freelance producer suggested to us that the pressure placed on the programming budget by these trends meant that the BBC wanted 'certainty in their output' and therefore 'tended to go for the certain middle ground' of programming. On this view, it was the preference of programme commissioners for a stock of reliable, economically produced programmes that was stifling innovation, as the chairman of an independent production company stated in interview:

we're the ones who kind of champion weird and wonderful ideas and we don't give up but it's the, as George Bush would describe it, the deciders within the broadcasting organisations who are risk averse and who kind of have the attitude, 'ohh, we haven't seen something like that before therefore it doesn't work', who make life very difficult.

If broadcasters are becoming more risk-averse when making commissioning decisions, this makes it difficult to attribute the perceived drift of formulism and repetition into significant segments of the programme schedule solely to the commercial imperative facing independent production companies. In our recent round of interviews, a senior BBC producer told us that in the current environment only a handful of producers are given autonomy over the production of ideas, suggesting that the primacy of 'bottom-up' creativity belonged to a bygone era:

I think those 10 years, about ' 85 to ' 95 ; there was an intense period of self-awareness and experimentation going on. In those years, and probably up to the late ' $90 \mathrm{~s}$, it was common for a commissioning editor to pull in a talented director and say what would you like to do? I want to hear your ideas. That doesn't really happen anymore. You'll get called in to ask whether you are interested in working on a particular project, which has already been pretty well defined by a commission.

This casts the BBC's management of competition between in-house and independent production teams in a new light, one in which the pragmatic needs of the commissioning function might take precedence over the insights and intuitions that emerge from the tacit mental models of television producers, whether developed inside or outside the BBC. This highlights that, although cognitive variety may be a significant source of creativity, its successful enactment depends on a favourable institutional environment that prizes 
innovation in the coordination of relations between television broadcasters and producers.

In summary, institutional analysis illustrates the direct bearing that the regulatory environment has on practices of innovation, altering the strategies of organisations as they respond to new opportunities produced by institutional reform. Attending to the process of institutional change showed that the production landscape which resulted from the reforms embodied particular agents' interests. One of the key mechanisms of change was political lobbying by PACT. The work of this group represented institutional entrepreneurship as they used an existing commissioning model (the ITV terms of trade) as a resource to lobby for legislative action on the supply of programming to broadcasters, thereby challenging the extant norms that guided supply relationships between the BBC and indies. As a process of institutional change, this resonates with the varieties-of-capitalism approach which regards the firm (and collectives e.g. producer associations) as a central actor in economic adjustment. However, what this interpretation of innovation neglects is the heterogeneity of interests reflected in institutional change. The broadcasting industry includes a range of organisations, from multimillion pound 'superindies' through to 'lifestyle companies' sustained by 'winning one or two commissions a year' (Mediatique, 2005, p. 8). PACT is perceived to be oriented towards the interests of larger indies as reflected in the association's subscription fees which are a fixed percentage of independents' revenue, thereby rising with size. For example, a former member of PACT's governing council, Nick Rosen, claimed that he was suspended from his post in 2007 for supporting the interests of smaller producers. In an article for The Guardian newspaper, Rosen (2007) summarised the issue facing smaller indies: 'In recent years, the large number of small, powerless production companies have seen their access to broadcasters diminish and a handful of large, powerful companies have strengthened their relationships considerably'.

While it would be wrong to speculate on the validity of Rosen's claim, his view does confirm that institutional change does not reflect necessarily the interests of all firms. As an illustration, fully-funded contracts, the alternative model of commissioning content that was sidelined in the reforms, carried the advantage of covering cost shortfalls that threaten smaller independents lacking the financial reserves of their larger counterparts (Deakin et al., 2009). As the concept of 'the firm' in varieties-of-capitalism approaches hides this diversity of interests, it fails to account for the specific patterns of innovation that characterise the development of industrial spaces. Institutional change has supported the growth of the independent production sector, but due to its 
variegated effect on firms and communities the industry's overall capacity for innovation and creativity may actually have declined (Mediatique, 2005).

\section{Conclusion}

This paper has examined the changing relationship between the BBC and the independent television production sector. A series of regulatory and organisational reforms over the last two decades has shifted the balance of power in favour of the independent production sector as a whole, with revenue doubling since 2000 on the back of new opportunities to produce programming for domestic broadcasters and to acquire greater export income based on the exploitation of ancillary rights. The issue at stake was whether these reforms have produced the intended regulatory benefit of stimulating creativity and innovation in public service broadcasting. For the independent sector, there have been both winners and losers. The change in the terms of trade has attracted City money into the sector, favouring the growth of 'super-indies' able to export lucrative programme formats worldwide. Equally, capitalisation has encouraged the consolidation of the sector, such that the interface with broadcasters is increasingly dominated by a handful of large indies, as lamented by critics who associate the decline of the small or 'lifestyle' indie with a loss of diversity in programming and the commercialisation of television. For the BBC, the introduction of competition between in-house and external production teams is undermining the reproduction of its own production communities, as commercial imperatives and norms take on greater precedence in the production and commissioning of programming.

According to the concept of cognitive distance, the injection of variety into the activities of CoPs should be no bad thing. Left alone, the innovative capacity of these groups is questionable (Wenger et al., 2002; Nooteboom, 2008). With regard to new competencies, extending the role of the independent sector has not introduced the novelty intended due to the embeddedness of the BBC's production capabilities in broader 'communities of ideas' that already embraces producers working within the independent sector (supported by their concentration in the media district of Soho). Instead, it is from an institutional perspective that greater distance between the BBC and the independent sector was detected. Notably, the profit motive facing 'super-indies' encourages new forms of organisational behaviour quite detached from the Reithian values still reified in the BBC's Royal Charter. The need to deliver year-on-year growth to satisfy investors encourages these companies to produce innovative programmes within profitable genres, but leaves gaps in other areas of provision. A member of the BBC Trust told us that a critical mass of in-house production remained important to deliver the more reflexive elements of public service broadcasting, 
as this requires 'a culture and career set of options that plays to serious, thoughtful values. The commercial market, we see, in some of these more challenging areas just won't do it'. The BBC's growing preference for using staff on freelance contracts brings the corporation steadily into line with the flexible working practices of the independent sector, and serves to hinder the reproduction of production communities that are committed to the public or aesthetic qualities of television. Furthermore, the routinisation of programming being led by the independent sector, and increasingly replicated by the $\mathrm{BBC}$, may render the reproduction of those values less important among producers.

The challenge for the BBC lies in maintaining cognitive diversity in the current programming schedule. To maintain variety, the BBC may need to provide greater support to the 'tail' of smaller independents. For example, C4, which works with the widest range of indies of the UK broadcasters, has a talent development programme, '4Talent', which invests $£ 10$ million per year to help create opportunities for individuals and small companies to make progress in the television industry, including a regional development programme based in Glasgow aimed at supporting SMEs outside Greater London (Channel Four, 2008). A manager linked to this initiative at C4 stated that the main concern of small companies lay in gaining access to programme commissioners, and competing with more established independents that have cultivated strong relationships with commissioning departments. To use Nooteboom's (1999) terminology, brokering novel relationships such as these would lay down 'cognitive bridging' mechanisms between small independents and commissioners, opening up a space through which the mutual understanding and knowledge of both parties could be enriched. This may also engender a commissioning dynamic that is less commissioner-dominated, in favour of one in which the producer's own ideas are given greater precedence as a source of cognitive diversity.

The enactment of this scenario, however, also presents a challenge to the literature on learning through communities, which often privileges micro-scale processes at the expense of broader structural concerns, such as the regulatory and institutional context that shapes the behaviour of organisations in different economic sectors. With regard to the recent reform of the UK broadcasting industry, insights from institutional theory constitute a useful analytical lens for making sense of the new forms of organisational behaviour observed. Institutional change altered the strategies of indies by encouraging creativity in popular forms of programming, based on the injection of a financially or commercially inflected set of values into programme-making. As such, analysis of communities of practice - groups regularly depicted as the locus of adaptation and innovation in the knowledge-based economy - should also consider the 
institutional constraints imposed upon these groups through structural mechanisms, a start being the political economy of public commissioning systems. 


\section{Notes}

1.A survey by Ofcom (2005) found that around $85 \%$ of the revenue generated by the independent sector was accounted for by production companies based in London.

2.This includes non-Network Nations and Regions programming.

3.The challenging working conditions facing many freelance workers within the UK television production industry in the 1990s have been well documented falling average earnings, requirements for multi-tasking, and derecognised unions (see Ursell, 2000). A recent Skillset (2008) report indicates that inequalities have persisted as, for instance, freelance workers in the television industry are less likely to receive formal training than permanent employees, with $37 \%$ of freelancers receiving some training over a twelve month between 2007 and 2008, compared to 64\% of permanent employees.

4. "Crowngate" refers to an incident that happened in 2007 involving the promotion of the documentary "A Year with the Queen", produced for the BBC by the independent company RDF Media. The promotional footage was misleading regarding the Queen's behaviour, and at the time some suspected that it had been wrongly edited so as to attract viewers. Although the investigation concluded that there had not been an intention to defame or misrepresent the Queen, it also pointed out that the incident revealed misjudgements, poor practice and ineffective control mechanisms (Wyatt, 2007).

5. Joint Committee on the Draft Communications Bill, Draft Communications Bill, Session 2001-02, Vol I, Ev. 289.

6. Joint Committee on the Draft Communications Bill, Minutes of Evidence, Qu. 539.

7. Ibid. Qu. 1012. 
8. These are: Kudos (acquired by Shine Group for $£ 35$ million in 2006); Tiger Aspect (acquired by Endemol for $£ 40$ million in 2009); Endemol; Talkback Thames; Lion Television (acquired by All3Media in 2004); 12 Yard Productions (acquired by ITV plc for $£ 35$ million in 2007); and Carnival Films (acquired by NBC Universal for $£ 30$ million in 2008). AIM listed Shed Media plc, owner of Shed Productions and Wall to Wall Television (ranked 8 and 9 respectively in the BBC's top 10), had an annual income of $£ 82$ million in 2008. The revenue of the other indie making up the top 10, Hat Trick Productions Ltd, is not known although a $45 \%$ stake in the business was sold to venture capitalists August Equity for $£ 23$ million in 2003. 


\section{References}

Amin, A. 2009. Extraordinarily ordinary: working in the social economy, Social Enterprise Journal 5.1: 30.49.

Amin, A. and Roberts, J. 2008. Knowing in action: Beyond communities of practice, Research Policy 37.2: 353-369.

BBC. 2004. Building public value: Renewing the BBC for a digital world, available at http://downloads.bbc.co.uk/info/policies/pdf/bpv.pdf, accessed June 2009.

BBC. 2009. Annual Report and Accounts 2008/09, available at http://www.bbc.co.uk/annualreport/download_trust.shtml, accessed April 2010.

BBC Trust. 2008. The Operation of the Window of Creative Competition (WOCC) First Biennial Review by the BBC Trust.

Born, G. 2002. Reflexivity and ambivalence: culture, creativity and government in the BBC, Cultural Values 6: 65-90.

Born, G. 2004. Uncertain Vision: Birt, Dyke and the Reinvention of the BBC, Secker and Warburg: London.

Born, G. 2005. 'Memorandum to the House of Lords Select Committee on BBC Charter Review', available at http://www.publications.parliament.uk, accessed April 2010.

Bryson, J., Keeble, D. and Wood, P. 1997. The Creation and Growth of Small Business Service Firms in Post-Industrial Britain, Small Business Economics 9: 345-360. 
Channel Four. 2008. Report and Financial Statements 2008, Channel Four Television Corporation: London.

Cowan, R., David, P., and Foray, D. 2000. The Explicit Economics of Knowledge Codification, Industrial and Corporate Change 9.2: 211-253.

Crouch, C. 2007. Capitalist Diversity and Change Recombinant Governance and Institutional Entrepreneurs. Oxford, Oxford University Press.

Crouch, C., Schroder, M., Voelzkow, H. 2009. Regional and sectoral varieties of capitalism, Economy and Society 38.4: 654-678.

D’Andrade, R. 1995. The development of cognitive anthropology, Cambridge: Cambridge University Press.

Deakin, S. and Pratten, S. 2000. Quasi Markets, Transaction Costs, and Trust, Television \& New Media 1.3: 321-354.

Deakin, S., Lourenço, A. and Pratten, S. 2009. No "third way" for economic organization? Networks and quasi-markets in broadcasting, Industrial and Corporate Change 18.1: 51-75.

DCMS. 2003. Tessa Jowell Responds to ITC Programme Supply Review, DCMS Media Release, January, available at http://www.cep.culture.gov.uk/, accessed April 2010.

DCMS 2005a. Review of the BBC's Royal Charter: A strong BBC, independent of government. Green Paper, DCMS: London.

DCMS 2005b. Government Response to the Lords Select Committee Report "Further Issues for BBC Charter Review”. Cm. 6787. DCMS: London.

DCMS 2006. A public service for all: the BBC in the digital age. White Paper, DCMS: London.

Doyle, G., Paterson, R. 2008. Public Policy and Independent Television Production in the U.K., Journal of Media Business Studies 5.3: 17-33. 
Faulkner, S., Leaver, A., Vis, F. and Williams, K. 2008. Art for Art's Sake or Selling Up? European Journal of Communication 23.3: 295-317.

Gherardi, S. 2009. Introduction: The Critical Power of the 'Practice Lens', Management Learning 40.2: 115-128.

Glaser, B.G. and Strauss, A.L. 1967. The Discovery of Grounded Theory,Aldine: Chicago.

Grabher, G. 2004. Temporary Architectures of Learning: Knowledge Governance in Project Ecologies, Organization Studies 25.9: 1491-1514.

Hall, P.A., Thelen, K. 2009. Institutional change in varieties of capitalism, SocioEconomic Review 7.1: 7-34.

Howell, J. 2003. Review: Varieties of Capitalism: And Then There Was One? Comparative Politics 36.1: 103-124.

Independent Television Commission. 2002. A Review of the UK Programme Supply Market. London: ITC.

Lampel, J., Lant, T. and Shamsie, J. 2000. Balancing Act: Learning from Organizing Practices in Cultural Industries. Organization Science 11.3:263269.

Lave, J. 2008. Epilogue: Situated Learning and Changing Practice. A. Amin, J. Roberts, eds. Community, Economic Creativity, and Organization. Oxford University Press, Oxford, 283-296.

Lave, J. and Wenger, E. 1991. Situated Learning: Legitimate Peripheral Participation, New York: Cambridge University Press.

Le Grand, J. and Bartlett, W. 1993. Quasi Markets and Social Policy. Macmillan: Basingstoke. 
Mediatique. 2005. From the Cottage to the City: the Evolution of the UK Independent Production Sector, Report Commissioned by the BBC, September, available at http://www.mediatique.co.uk/reports.html, accessed June 2009.

Mediatique. 2008. All Grown Up: Cash, Creativity and the Independent Production Sector, An independent report by Mediatique Limited, available at http://www.mediatique.co.uk/reports.html, accessed June 2009.

Nachum, L. and Keeble, D. Neo-Marshallian Nodes, Global Networks and Firm Competitiveness: The Media Cluster of Central London, Working Paper No. 138, ESRC Centre for Business Research, University of Cambridge.

Nelson, R.R. and Winter, S. 1982. An Evolutionary Theory of Economic Change, Cambridge, MA: Belnap Press of Harvard University Press.

Nooteboom, B. 1999. Innovation, learning and industrial organisation, Cambridge Journal of Economics 23: 127-150.

Nooteboom, B. 2000. Learning by Interaction: Absorptive Capacity, Cognitive Distance and Governance, Journal of Management and Governance 4: 6992.

Nooteboom, B. 2008. 'Cognitive Distance in and Between Communities of Practice and Firms: Where Do Exploitation and Exploration Take Place, and How Are They Connected?', Amin A. and Roberts J. (eds) Community, Economic Creativity, and Organization. Oxford: Oxford University Press: 123-147.

Nooteboom, B., Berger, H. and Noorderhaven, N.G. 1997. Effects of Trust and Governance on Relational Risk, Academy of Management Journal 40.2: 308-338.

North, D.C. 1990. Institutions, Institutional Change and Economic Performance, Cambridge, Cambridge University Press.

North, D.C. 1993. Economic Performance Through Time, The American Economic Review 84.3: 359-368. 
Ofcom. 2004. Ofcom review of public service television broadcasting. Phase 1 Is television special?, available at http://www.ofcom.org.uk, accessed March 2010.

Ofcom. 2005. Television Production Sector Review: A Survey of TV programme production in the $U K$, available at http://www.ofcom.org.uk, accessed June 2009.

Ofcom. 2009. Public Service Broadcasting: Annual Report 2009, available at http://www.ofcom.org.uk, accessed April 2010.

Oliver and Ohlbaum. 2009.The Economics of UK TV Content Supply Challenges and Opportunities to 2020, London, Oliver and Ohlbaum Associates.

Perspective. 2009. Digital Britain: Assessing the policy framework for Public Service Rights, London, Perspective Associates.

Powell, W. 1990. Neither market nor hierarchy: network forms of organisation, Research in Organizational Behaviour 12: 295-336.

Roberts, J. 2006. Limits to Communities of Practice. J. of Management Stud. 43(3) 623-639

Rosen, N. 2007. On a mission for minnows, The Guardian, 19 March.

Shed Media plc. 2008. Annual Report and Accounts 2008, available at http://www.shed-media.com/inv/inv-reports.html, accessed June 2009.

Skillset. 2008. Television Sector - Labour Market Intelligence Digest, available at http://www.skillset.org/research/, accessed June 2009.

Starkey, K., Barnatt, C., and Tempest, S. 2000. Beyond Networks and Hierarchies: Latent Organizations in the U.K. Television Industry, Organization Science, 11. 3: 299-305. 
Teece, D.J., Pisano, G., and Shuen, A. 1997. Dynamic Capabilities and Strategic Management, Strategic Management Journal 18.7: 509-533.

The Guardian. 2009. 'UK independent producers earn record £391m from overseas TV sales' (Guardian.co.uk), 3 June.

Ursell, G. 2000. Television production: issues of exploitation, commodification and subjectivity in UK television labour markets, Media, Culture \& Society 22: 805-825.

Wenger, E. 1998. Communities of Practice: Learning, Meaning, and Identity, Cambridge: Cambridge University Press.

Wenger, E., McDermott, R., and Snyder, W.M. 2002. Cultivating Communities of Practice: a guide to managing knowledge, Boston, MA: Harvard Business School Press.

Work Foundation. 2005. The Tipping Point, How Much is Broadcast Creativity at Risk? Report Commissioned by the BBC, July, available at www.theworkfoundation.com/publications/, accessed October 2007.

Wright, J.S. 2009. The regulatory state and the UK Labour Government's reregulation of provision in the English National Health Service, Regulation \& Governance, 3.4: 334 - 359.

Wyatt, W. 2007. Investigation into A Year with the Queen. British Broadcasting Corporation, available at http://www.bbc.co.uk/pressoffice/, accessed July 2009. 
